RESEARCH ARTICLE

\title{
ETHICAL POLICY IN HIGHER EDUCATION SCHOOL OF LAW: CASE OF UNIVERSITAS NEGERI SEMARANG
}

\author{
Batari Laskarwati ${ }^{1 \bowtie}$, Rodiyah ${ }^{2}$ \\ ${ }^{1}$ Transcosmos Indonesia Company, Indonesia \\ ${ }^{2}$ Faculty of Law, Universitas Negeri Semarang, Indonesia \\ $\triangle$ batarilaskarwati@gmail.com
}

\section{CITED AS}

Laskarwati, B., \& Rodiyah, R. (2020). Ethical Policy in Higher Education School of Law: Case of Universitas Negeri Semarang. Journal of Law and Legal Reform, 1(4), 649670. https://doi.org/10.15294/jllr.vli4.39893

\section{ABSTRACT}

This study is intended to analyze and describe the urgency of campus life ethics policy at the Faculty of Law and how ethical policy constraints campus life at the Faculty of Law. The study also aims to find obstacles in implementing the Campus Life Ethics Policy at the Faculty of Law. The concepts and theories in this study are the basic concepts of ethics and policy theory, policy implementation, legislative hierarchy, ethics, and legal system theory according to Lawrence Friedman. This type of research is a sociological juridical study with a qualitative research approach. Sources of research data come from primary data (interviews) and secondary data (literature studies and documentation). The data collection technique of this study used observation, interviews, and study of documents. This study found and revealed that there are two factors (internal and external) affected to student behaviors. Internal factors include character of students themselves, student habits, apathetic cultural factors inherent in students, and external factors include incomplete facilities, lack of in-depth socialization, lack of supervision and strict enforcement as well as interference from outside UNNES. The study concluded that the Campus Life Ethics at the Faculty of Law UNNES is able to be realized with in-depth socialization of the Regulations Chancellor Number 44 of 2018 is accompanied by supervision and strict enforcement of sanctions.

Keywords: Student Ethics, UNNES; Policy Implementation; Urgency; Problems, Challenges 


\section{TABLE OF CONTENTS}

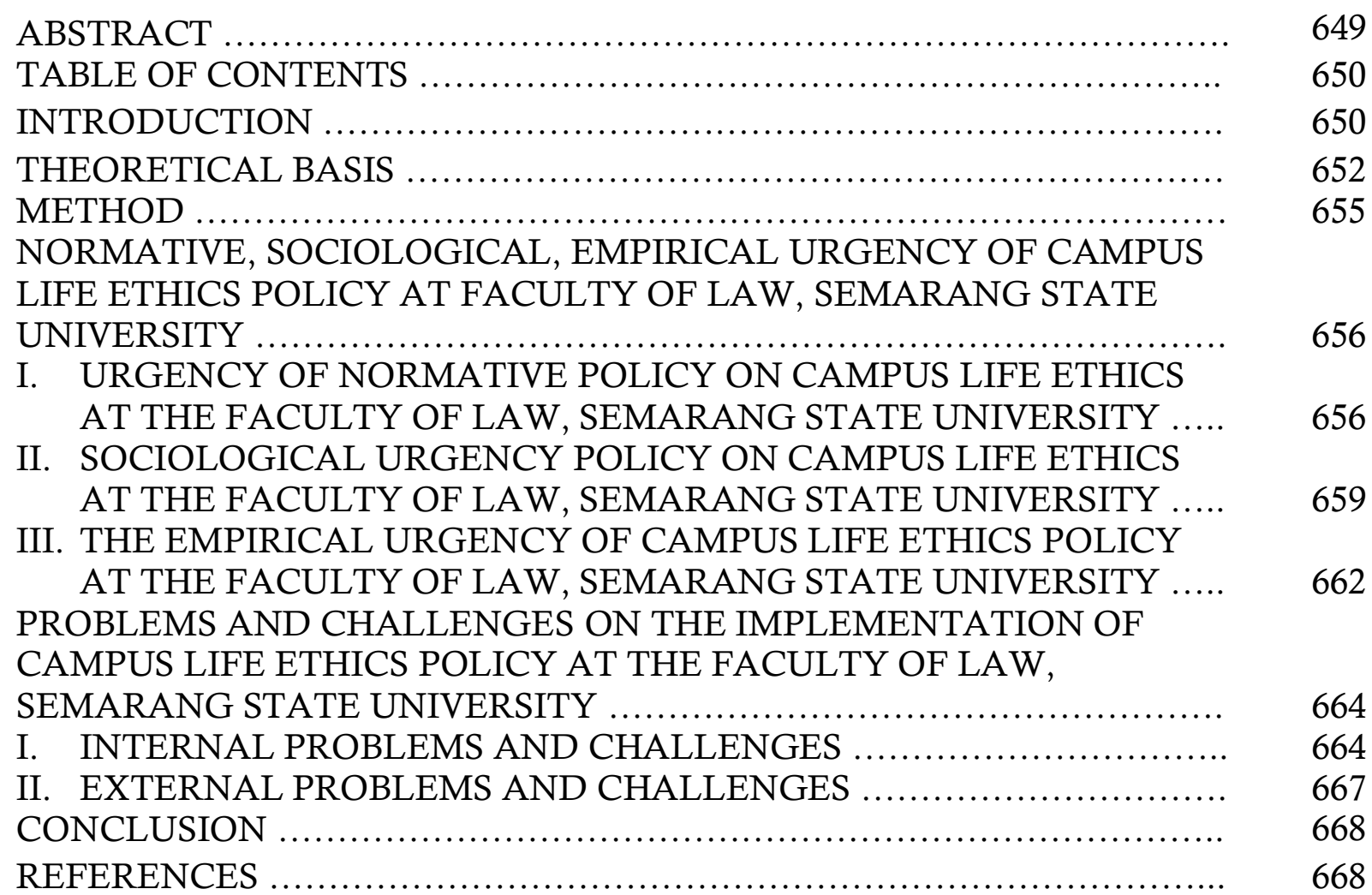

\section{INTRODUCTION}

Semarang State University (UNNES) is one of the State Universities in the city of Semarang. In 2019, Semarang State University has a vision to become a university with a conservation and international reputation. Semarang State University has 8 Faculties, including: Faculty of Education, Faculty of Language and Art, Faculty of Social Sciences, Faculty of Mathematics and Natural Sciences, Faculty of Engineering, Faculty of Sports, Faculty of Economics and Faculty of Law.

UNNES as a conservation university is a university that is in the implementation of education, research, and community service based on conservation principles, such as the protection, preservation and sustainable use of natural resources, the environment, human resources, arts, and culture (Rodiyah, 2017).

In 2019 Semarang State University has 8 Faculties and Postgraduate Programs with a significant number of students. The total number of Semarang State University students in 2019 was 29,087 students (source: data.unnes.ac.id). 
Table 1. Data of UNNES Active Students in 2019 January

\begin{tabular}{llrrr}
\hline No. & \multicolumn{1}{c}{ Program } & $\begin{array}{c}\text { Male } \\
\text { student }\end{array}$ & $\begin{array}{r}\text { College student } \\
\text { Girl }\end{array}$ & $\begin{array}{c}\text { Number of } \\
\text { students }\end{array}$ \\
\cline { 2 - 5 } & Undergraduate Program & & 3,288 & 4,177 \\
\hline 1 & Faculty of Science Education & 889 & 3,060 & 4,459 \\
2 & Faculty of Language and Art & 1,399 & 1,626 & 2,644 \\
3 & Faculty of Social Science & 1,018 & 2,636 & 3,475 \\
4 & Faculty of Math and Science & 839 & 1,286 & 3,055 \\
5 & Faculty of Engineering & 1,769 & 1,240 & 3,063 \\
6 & Faculty of Sport Science & 1,823 & 2,703 & 3,667 \\
7 & Faculty of Economics & 964 & 785 & 1,476 \\
8 & Faculty of Law & 691 & 1,730 & 3,071 \\
9 & Postgraduate Program & 1,341 & 18,354 & 29,087 \\
\hline \multicolumn{7}{c}{ Total } & 10,333 & & \\
\hline
\end{tabular}

The 1945 Constitution in its opening mandate has mandated that, one of the goals of the nationhood of Indonesia is to educate the life of the nation, in this case the University has an important role in educating the generation of the Indonesian nation. Through education in Higher Education, which in this case is a place where humans are given education to be able to humanize humans. Specifically for UNNES students, students must be able to condition their behavior in the local community of Sekaran, Patemon, Sukorejo, and Kalirejo. The local community around UNNES is often referred to as the SEPASUKA community (Sekaran, Patemon, Sukorejo, and Kalirejo).

Students as agents of change must have basic provisions before entering the community, one of which is to be ethical in the campus environment. Student ethics can be seen in students living on campus. Students themselves in ethics also need a guide in attitude or ethics. In this case, UNNES has the Chancellor Regulation Number 19 of 2016 concerning the Ethics and Code of Conduct of UNNES Students and then there is a regulation governing the same thing, Rector's Regulation Number 44 of 2018 which was ratified in December 2019. The Rector's Regulation is useful to support the Atmosphere Academic in campus life.

shoes worn by students do not match the appeal in the Faculty of Law. Another violation committed by students of the Faculty of Law is cheating, this practice is still perpetrated by students. Another phenomenon encountered by researchers is parking habits that are not in accordance with the rules set. The parking area at Semarang State University has been arranged in such a way, but in fact, many students are parking anywhere and outside the designated parking area. The phenomenon of violations committed by these students is contrary to the Chancellor's Regulation No. 
44 of 2018 concerning Ethics and Rules of Order of Semarang State University students. This research will discuss the Urgency of Campus Life Ethics Policy at the Faculty of Law, Semarang State University which includes Normative, Sociological and Empirical Urgency. In addition, researchers will also discuss the Obstacles to the Implementation of Campus Life Ethics Policy at the Faculty of Law, Semarang State University.

\section{THEORETICAL BASIS 1. Basic Concepts of Ethics}

Ethical choice is a problem for humans who have the freedom to choose (Kenneth, 2007; 155). Here are the basic concepts of ethics:

1) Responsibility

Responsibility is the most important element of ethical action. Responsibility means that you accept all costs, obligations and obligations that will arise as a consequence of the decision you make.

2) Accountability

Accountability is a characteristic of social systems and institutions: this means that there is a mechanism that determines who takes responsible action, who is responsible. Systems and institutions that are difficult to determine who takes what action will fail to conduct ethical analysis or ethical actions.

3) Liability

A liability is a feature of a political system in which a legal entity takes on the role of giving permission to individuals to repair losses caused by other actors, systems or organizations.

Talking about ethics, certainly cannot be separated from the character. A character is developed through the stages of knowledge (knowing), implementation (acting), and habits (habits). Character is formed through the development of the elements of human dignity (HMM) which are entirely in accordance with the noble values of the Pancasila. More detailed, the dignity and value (HMM) include three basic components, namely human nature, human dimensions, and humanitarian principles (Prayitno \& Barferik, 2011: 47-48). 


\section{Hierarchy Theory}

Hierarchy theory is a theory about the legal system introduced by Hans Kelsen which states that the legal system is a ladder system with tiered rules. The relationship between norms governing the actions of other norms and other norms can be called a super relationship and sub-ordination in a spatial context (Asshiddiqie \& Safa'at, 2010: 110).

\section{Policy}

Policy is a series and principles that outline and base the plan for carrying out a leadership job, and how to act (the way the organization or government); statement of ideals, goals, principles, or intentions as a guideline for management in an effort to achieve certain goals (Balai Pustaka, 1991 in Dachi 2017).

\section{Policy Implementation Theory}

Theories regarding the implementation of policies put forward by several experts include:

a) Theory of Donald S. Van Meter and Carl E. Van Horn

According to Meter and Horn, there are six variables that affect implementation performance, namely:

1) Policy standards and objectives.

Policy standards and objectives must be clear and measurable so they can be realized.

2) Resource.

Need to support resources both human resources (human resources) and nonhuman resources (non-human resource) to implement policies.

3) Relations between Organizations.

the implementation of a program needs support and coordination with other agencies especially in many programs.

4) Characteristics of the implementing agent.

The characteristics of implementing agencies are the scope of the bureaucratic structure, norms, and patterns of relationships that occur in the bureaucracy, all of which will affect the implementation of a program. 
5) Social, political and economic conditions.

The scope of this variable is environmental economic resources that support successful policy implementation. The implementor's disposition includes three important things, in the form of: the implementor's response to the policy, which will affect his willingness to carry out the policy. And the intensity of the implementor's disposition, namely the value preferences held by the implementor.

b) Theory of George C. Edwards III

Edwards III's view, policy implementation is influenced by four variables, namely:

(1) communication, (2) resources, (3) disposition, and (4) bureaucratic structure. The four variables are also interconnected with each other (Edward III, 1980; 1).

1) Communication

prerequisites for successful implementation of the policy are the implementor knows what needs to be done. The policy objectives and targets must be transmitted to the target group so that they will reduce the distortion of implementation. If the goals and objectives of a policy are unclear or even unknown to the target group, then there is a possibility of resistance from the target group.

2) Resource

Although the policy has been clearly and consistently communicated, if the implementor lacks the resources to implement the policy, the implementation will not be effective. These resources can be in the form of human resources, namely the implementor's competence and financial resources. Resources become an important factor for policy implementation to be effective. Without resources, policies only remain on paper as documents.

3) Disposition

Disposition is the character and characteristics of the implementor. if the implementor has a good disposition, then he will run the policy as well as what is desired by policy makers. When the implementor has a different attitude or perspective from the policy maker, the policy implementation process also becomes ineffective. various development experiences in third world countries show that the level of commitment and honesty of the authorities is low. Various cases of corruption that have arisen in third world countries, such as Indonesia, are concrete examples of the low commitment and honesty of the authorities in implementing development programs. 


\section{4) Bureaucratic Structure}

The organizational structure has a significant influence on policy implementation because the bureaucratic structure is tasked with implementing the policy. One of the important structural aspects in organizations is the existence of standard operating procedures (SOPs). SOP is a guideline for every implementor in acting.

Organizational structure that is too long will tend to weaken supervision and lead to red-tape, which is a complex and complex bureaucratic procedure. This in turn results in inflexible organizational activities (Edward III, 1980).

\section{METHOD}

The research method used in this study is to use a qualitative approach. Qualitative approach is a way of analyzing research results that produce descriptive analysis data, that is data stated by respondents in writing or verbally as well as real behavior, which is thoroughly researched and studied (Mukti, 2010; 192). This type of research is sociological juridical, namely research that emphasizes the behavior of individuals or communities in relation to law (Marzuki \& Peter, 2005: 128). The focus of research in this study is the Urgency of Campus Life Ethics Policy at the Faculty of Law being the needs of students of the Law Faculty of Semarang State University in the perspective of Rector Regulation Number 44 Year 2018 and the constraints on implementing Campus Life Ethics Policy at the Law Faculty of Semarang State University in the perspective of Rector Regulation Number 44 Year 2018 The location of this research was conducted in the Faculty of Law, Semarang State University. The data source used in this study is primary data which includes the results of interviews and observations and secondary data which includes literature and documentation data. Data collection techniques in this study were by observation, interview, and documentation. In this study, the data analysis process was carried out in four stages, namely data collection, data reduction. 


\section{NORMATIVE, SOCIOLOGICAL, EMPIRICAL URGENCY OF CAMPUS LIFE ETHICS POLICY AT FACULTY OF LAW, SEMARANG STATE UNIVERSITY}

The urgency of the Campus Life Ethics Policy is needed to find out how far this policy is needed in regulating student ethics and discipline. The following will describe the urgency in terms of normative, sociological, and empirical.

\section{URGENCY OF NORMATIVE POLICY ON CAMPUS LIFE ETHICS AT THE FACULTY OF LAW, SEMARANG STATE UNIVERSITY}

Rector's Regulation No. 44 of 2018 concerning Ethics and Student Order of Semarang State University is UNNES official regulation that regulates the attitudes, actions, or behavior of students both on campus and off campus.

UNNES students totaled 29,087 students. So, with such a large number of students a rule is needed to regulate the attitudes, actions and behavior of students in living on the campus of Semarang State University. Therefore, Semarang State University made Rector Regulation No. 44 of 2018 concerning Ethics and Rules of Conducting of Semarang State University Students.

Nawiasky has a theory called theorie von stufenufbau der rechtsordnung. Arrangement of norms according to the theory is the fundamental norms of the state (Staatsfundamentalnorm), the basic rules of the state (Staatsgrundgesetz); Formal Law (Formell Gesetz); and Implementation regulations and autonomous regulations (Verordnung En Autonome Satzung). Staatsfundamentalnorm is the norm that is the basis for the formation of the constitution or Basic Law (staatsverfassung) of a country. The legal position of a Staatsfundamentalnorm is as a condition for the application of a constitution. Fundamental norms exist before the constitution of a country (Atamimi, 1990: 287).

Based on the Nawiaky theory, A. Hamid S. Attamimi compared it to Kelsen's theory and applied it to the structure of the legal system in Indonesia. Attamimi shows the structure of the Indonesian legal hierarchy using Nawiasky's theory. Based on this theory, the structure of Indonesia's legal system is (Atamimi 1990: 287): 
1) Staatsfundamentalnorm: Pancasila (Opening of the 1945 Constitution of the Republic of Indonesia).

2) Staatsgrundgesetz: Body of the 1945 Constitution, MPR Decree, and Convention

3) Constitution.

4) Formell Gesetz: Constitution.

5) Verordnung en Autonome Satzung: Hierarchically from Government Regulation to Decree of Regent or Mayor.

The position of the Chancellor's Regulation No. 44 of 2018, explained by Ali Masyar as Vice Dean and Former of Expert Staff in Law and one of the Ethics Council members at Semarang State University, is as follows:

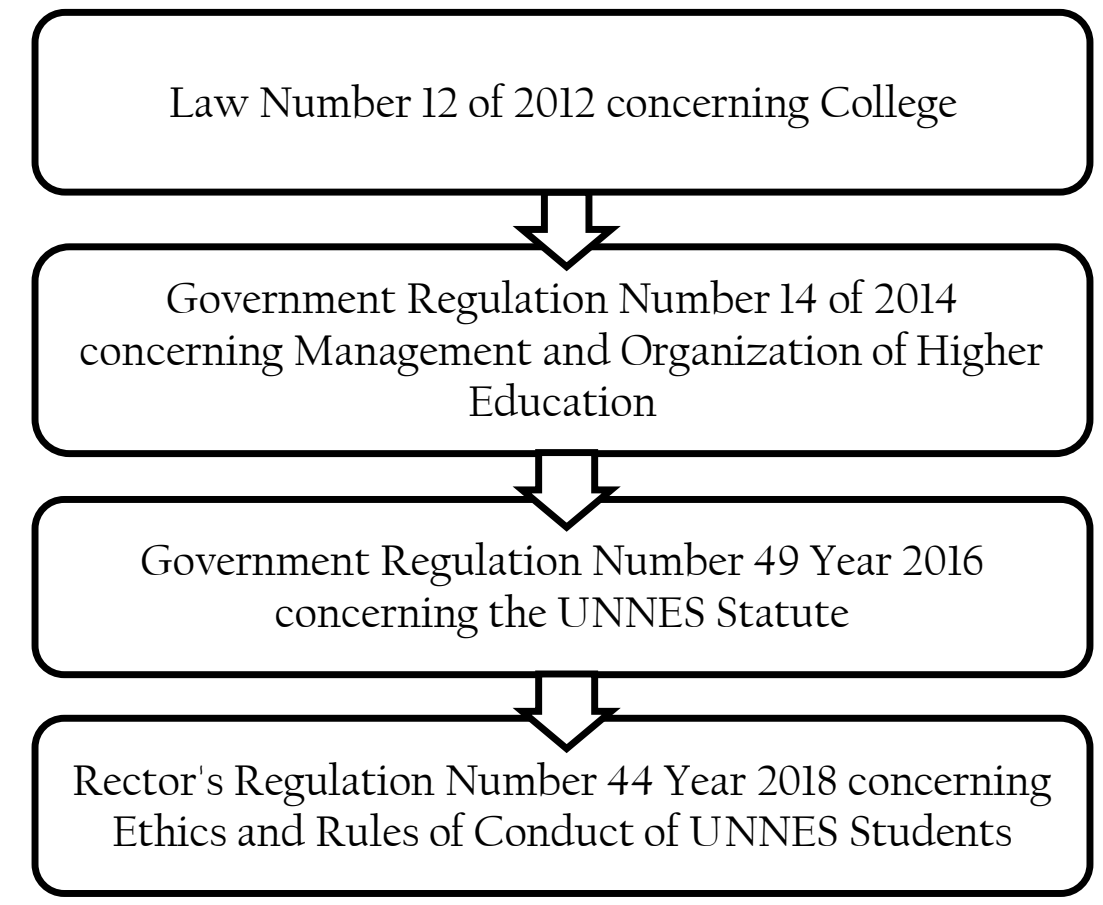

Figure 1. Diagram of Legal Position of Rector's Regulation Number 44 Year 2018

Based on the statement described above, matters regarding the urgency of the Rector's Regulation Number 44 Year 2018 were also conveyed by Ali Masyar as the Chair of the Research and Community Service Development and Public Service Cluster and at the same time serving as an Expert Staff in Law and one of the Ethics Council members in Semarang State University, explained that the function of the Chancellor Regulation Number 44 Year 2018 is for students to be on the right track, or to be on the right track. Mr. Ali added that the UNNES institution provided a Regulation that was in line with Unnes Vision and Mission, and that students would 
not cross the rails or stay on the right track. But in fact, on the ground there are still many who violate the policy, this is due to several factors,

In addition to the Ethics Council as a policy supervisor, in fact, the Law Faculty has provided controls, one of which is the creation of an exhibitor on communication ethics, dress ethics and boards containing moral messages. as stated by Nurul Febrianti as Chairman of the Business Development, Career and Alumni Cluster who explained that for knowledge through exhibitors, then there are writings on the walls emphasizing moral education which is written in nature, if verbally, for example is a reprimand, like not may sit at the table. So, the reprimands tell and give understanding to them that this is wrong, but let the students be right, because there is no reprimand. The following is a writing board on the wall of FH UNNES on the Ethics of No Cheating and no plagiarism as shown on Figure 2 and Figure 3.
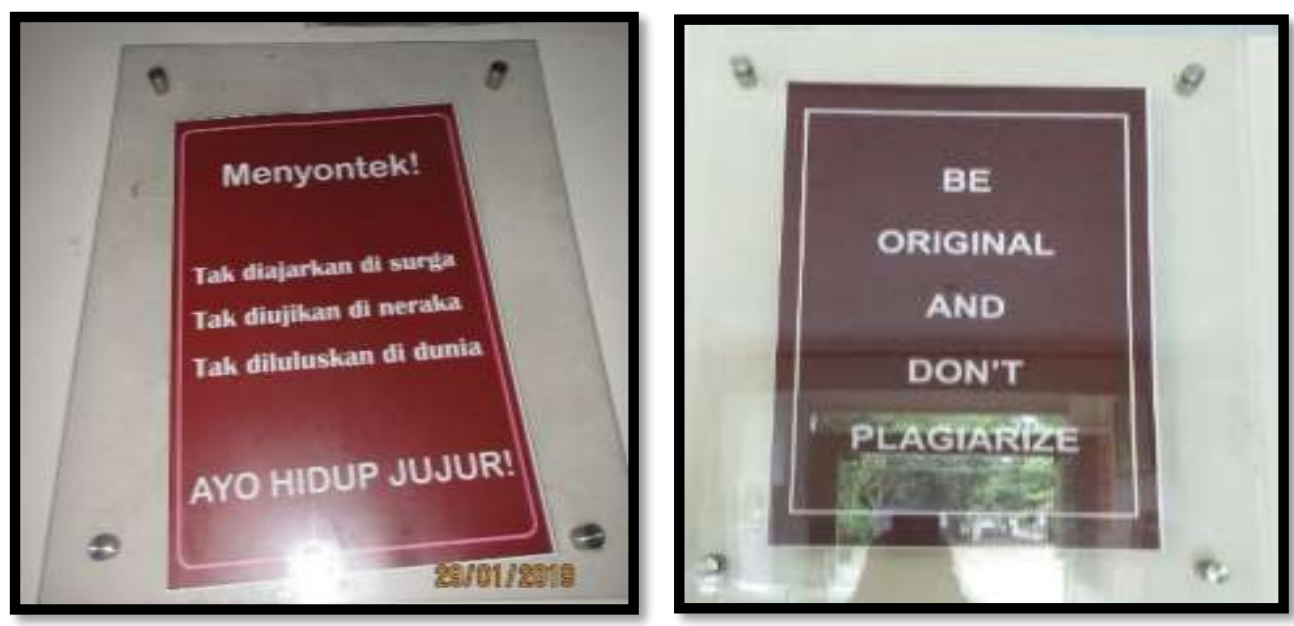

Figure 2, Figure 3. Examples of Ethical Policy in Faculty of Law UNNES

In addition to the socialization, there were also exhibitors about dress ethics and communication ethics with lecturers at the Faculty of Law UNNES, in this case, the need for exhibitors at several points was not just 1, 2 points, but if necessary there were floors in the campus. Next are the Former Ethics Banner in FH UNNES and the Former Ethics Banner in Communication with Lecturers by Mobile Phones as shown on Figure 4 and Figure 5. 

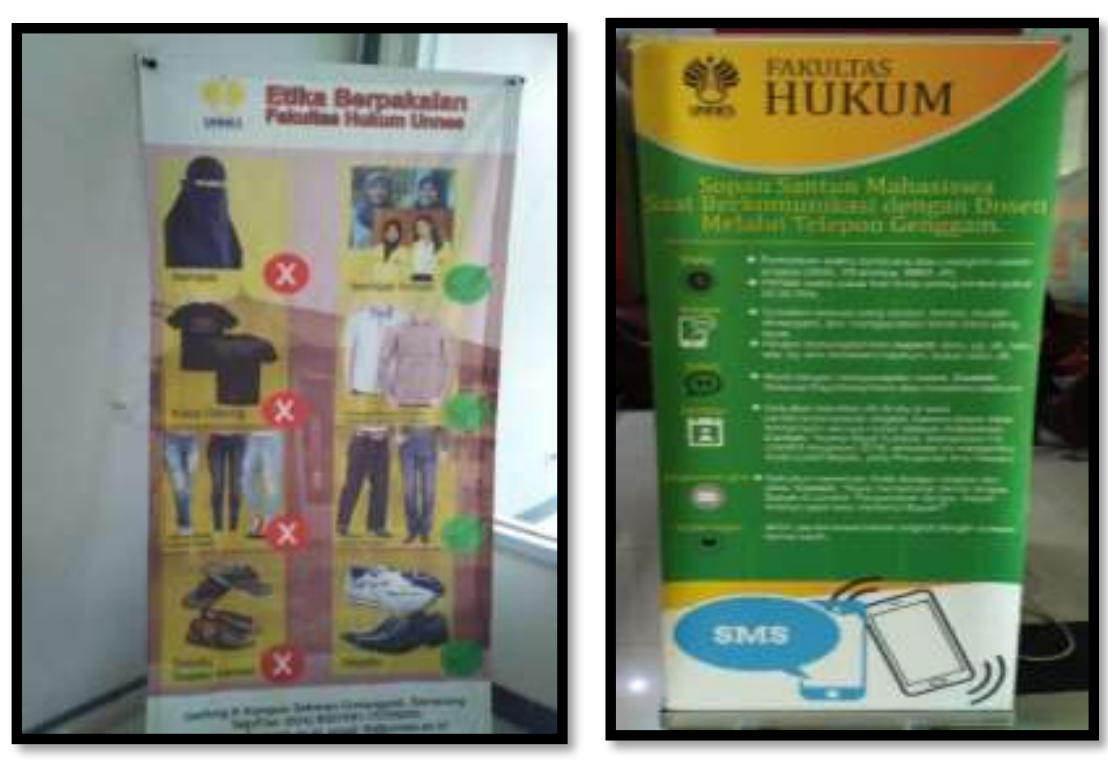

Figure 4, Figure 5. Examples of Ethical Policy (Communication and Attitude Policy)

In addition to the preventive control that has been applied by the faculty, in the form of exhibitors and display of words that are positive, it is good that the lecturer gives a good example to students, becoming role models for students. This is the same as stated by Aprila Naravita, as Secretary of the Collaborative Development Cluster, PKL and KKL who provide an explanation that there must be role models in this lecturer, because it is useless to be socialized loudly but not balanced with good role models. from the lecturer.

\section{SOCIOLOGICAL URGENCY POLICY ON CAMPUS LIFE ETHICS AT THE FACULTY OF LAW, SEMARANG STATE UNIVERSITY}

Sociological urgency is also needed considering in life on campus certainly involves the community, namely the community within the campus itself, besides that students are also closely related to the community outside the campus where, good ethics or good character must be owned by students to socialize on campus and off campus. One way to build character is through education. Existing education, be it education in the family, community, or formal education in schools must instill the values of character formation (Syamsul, 2014: 30). Building good character through education can be through character education. Characterization is character education plus, 
Speaking about the formation of character in the school or campus environment, one of which is the existence of regulations or policies implemented by a college, according to Ridwan Arifin's statement above the function of the policy is to shape the character of students. Thus, it is hoped that through the Chancellor's Regulation No. 44 of 2018 on Ethics and Rules of Conduct, it will be able to shape the character of good students.

Students in social life must naturally be armed with good ethics, so that the community responds well. In ethics, students must know the basic concepts of ethics, and here are the basic concepts of ethics (Kenneth, 2007: 155):

1. Responsibility

Responsibility means that you accept all costs, obligations and obligations that will arise as a consequence of the decision you make. In terms of responsibilities, students have learned responsibility from activities on campus, namely when students take part in intra and extra campus activities. The intra and extra campus ethics also affects the personality or character of the student. An example is UKM Scout as an organization that emphasizes the formation of student character. Mohammad Zacki Pratama asserted that by participating in Scouting UKM, understanding of the duties and responsibilities is also taught.

2. Accountability

Accountability is a characteristic of social systems and institutions: this means that there is a mechanism that determines who takes responsible action and who is responsible. The manifestation of accountability in this research is the presence of an Ethics Board whose task is to impose sanctions on students who violate them. The one who is responsible of course is the student who commits the violation, because the student is already considered an adult human who can be responsible for everything that happens due to his actions. One member of the Ethics Board is the Commander of the security guard, who can provide affirmative action prior to the realm of an ethics session such as reprimanding if there are students who park improperly in the parking lot. Thus, the accountability in the ethical concept in this research is fulfilled by the Ethics Board that determines who is responsible for any violations or problems.

3. Liability

A liability is a feature of a political system in which a legal entity takes on the role of giving permission to individuals to repair losses caused by other actors, systems or organizations. The manifestation of the liability in this study is that it allows students to apologize for their mistakes. Students who make mistakes (level 1) are given guidance by the campus at the faculty, then when it cannot be handled by 
the faculty, then submit it to the University level Ethics Board. But in this case, students are very permitted to improve themselves, with certain conditions such as promises on the stamp will not repeat the mistakes that have been made.

Tri Sulistyono as Vice Dean of the Faculty of Law explained that the Ethics Board will convene if there is a serious violation, if the violation is minor or is handled by the Faculty, so initially there is an incoming report related to violations committed by students, then analyzed by the Ethics Board into violations what, if it is mild, it will be handled by the Faculty, if it is entered into a serious violation, it will be held at the university level. Ali Masyar as a member of the University level Ethics Board revealed that, the Faculty has autonomy in making policies and handling when a problem occurs, with a note that it is still in the reasonable category and does not exceed the limits. so initially there was a report on admissions related to violations committed by students, then analyzed by the Ethics Board in what violations, if mild they would be handled by the Faculty, if entered into serious violations it would be heard at the University level. Ali Masyhar as a member of the Ethics Board at the University level revealed that, the Faculty has autonomy in making policies and handling when a problem occurs, with a note that it is still in the reasonable category and does not exceed the limits. so initially there was a report on admissions related to violations committed by students, then analyzed by the Ethics Board in what violations, if mild they would be handled by the Faculty, if entered into serious violations it would be heard at the University level. Ali Masyhar as a member of the University level Ethics Board revealed that, the Faculty has autonomy in making policies and handling when a problem occurs, with a note that it is still in the reasonable category and does not exceed the limits.

Students only need to be accustomed in the way they should be. Therefore, this regulation is very important to shape the character of UNNES students in life on campus and off campus. Therefore, students must start in order or in order from small things, until later in creating big things also orderly. Rodiyah explained that the small things we must order to create the big things, all those people will obey the rules when we all uphold with love.

The role of students in the community was carried out by Regita Prameswari, a 2017 class of FH UNNES student who took part in an extra-campus organization, IPNU which was a social service activity at an orphanage. This shows that good character is obtained from organizations that are followed on campus and off campus. With regard to intra and extra-campus activities, ethics in behavior is also written and unwritten. Examples of ethics written in the AD/ART of each organization. The unwritten ethics are a habit. 
This is in accordance with Arifin's statement, Students of 2016 who joined UKM Linguabase (intra-campus) explained that there are AD/ART, for example drinking alcohol, should not gossip with one another. Based on the above interview, it is clear that the character of students is formed not only in lectures but when students join the organization both intra and extra-campus, where each organization has its ethics both written and unwritten which has a pretty good impact for the UNNES and SEPASUKA community (now, Patemon, Sukorejo, and Kalirejo).

\section{THE EMPIRICAL URGENCY OF CAMPUS LIFE ETHICS POLICY AT THE FACULTY OF LAW, SEMARANG STATE UNIVERSITY}

Student Ethics and Code of Conduct is no stranger to students who have been educated in Higher Education. However, although familiar, in reality there are still many students who do not understand the Ethics and Rules of Conduct as students. Violations committed by Faculty of Law UNNES students include smoking in the campus area, cheating, improper parking, wearing $t$-shirts during lectures, wearing short clothes (not polite) when in college, wearing sandals. As stated by one of the 2015 Faculty of Law UNNES students, Mariyatul Qibtiyah, who stated that they often see people smoking or students smoking in the gazebo, smoking in the canteen, and parking lots, as well as some students cheating during exams.

The Faculty of Law has provided enforcement of smoking offenses in the form of making statements from students who are accompanied by KTM not to repeat. Some facts that occur in the field suggest that there are still many students who commit violations. Therefore, this regulation is important in order to regulate students in order to be lawful.

Based on research conducted by researchers, some students who have been interviewed by researchers, the results are all students who do not understand anything related to ethics and order as students at UNNES, students only understand related to dress code, the rest they lack understanding.

Baidhowi stated that students' misunderstanding and ignorance regarding the Policy on Campus Life Ethics in addition to the lack of socialization was also due to student apathy. The understanding of students related to ethical policies in living on campus is very important, so there must be clear socialization related to the Ethics and Code of Conduct, considering that students' Ethics and Rules are used in living on campus and off campus. Ali Masyhar as chairman of the Research and Community 
Service Development and Publication Cluster, UNNES Rector Expert Staff in Law, and a member of the Student Ethics Board stated that socialization was already in place by each faculty which was integrated at the time of PPAK, in PPAK there was material on Ethics in Campus life, but because of the time that makes it less absorbent for students. Ignorance of students related to Ethics and Order of students makes violations of Ethics and Rules occur, this is the same as conveyed by Erina Fionita Nurfajila (Political Science Student, 2016, Vice President of BEM KM 2019) that the regulations may not have been fully socialized, for example if the law is known or not deemed to know. Thus, the student finally does something unknown.

Lawrence M. Friedman argues that the effectiveness or success and success of a legal system depends on three legal elements, namely the legal, legal structure, legal culture.

\section{Legal Substance}

The substance of law (substance rule of the law). The substance of the law (substance rule of the law), therein encompasses all written and unwritten rules, both material and formal law. Legal substance in the form of written rules in this study is Rector's Regulation Number 44 Year 2018 concerning Student Ethics and Rules and Appeals in the form of banners from each Faculty at Semarang State University which are determined and agreed upon by the Faculty, and habits that live at the University Semarang State in general and the Semarang State University Law Faculty in particular. Submission or outreach of this policy in the form of written rules and habits that are considered good by the surrounding environment such as the need to be polite and polite to the campus community such as lecturers and students.

The above theory and interviews show that the legal substance at UNNES in general and the Faculty of Law in particular is written and unwritten law as well as formal and material law.

\section{Legal Structure}

Kelsen (2013) suggests the structure of the law (structure of the law), covers legal institutions, legal apparatus and law enforcement systems. The legal structure is an element of the procedure of legal formation and legal form (in the sense of substance and hierarchy). According to Lawrence Friedman that the structure is a strong characteristic that is formed slowly by the strength of social forces in the long run, which modified the claim will take place and on it long-term deposits from other social demands (Hidayat, 2017: 195). Legal structure in this study are:

a. Legal institutions in this study are Rector's Regulation No. 44 of 2018 concerning Ethics and Rules of Conduct of UNNES Students. 
b. Legal Apparatus, namely policy-making officials, namely the Chancellor of UNNES, Deputy Chancellor for Student Affairs, UNNES Ethics Council, Deans, Vice Deans for Student Affairs, Ethics Council of the Faculty of Law UNNES. The structure of the Ethics Board can be seen in the attachment of this thesis.

c. Law enforcement in this study was carried out starting from reports of student violations that violated ethics and discipline on campus, then was given guidance at the faculty level, and then when serious violations would be handed over to the University, the UNNES Student Ethics Board. Severe violations can lead to sanctions in the form of Rector's Decree ranging from suspension to Drop Out (DO). Law Enforcement can be seen in the content of Rector's Regulation Number 44 Year 2018 CHAPTER VI Article 11.

3. Legal Culture

Legal Culture is an emphasis on the culture in general, habits, opinions, ways of acting and thinking, which direct social strength in society. Legal culture is needed to make good habituation to students. The legal culture that has been carried out in the law faculty is habituation to law students to avoid plagiarism, the habituation is always stated by the lecturer in verbal speech while teaching in class and students are always directed to include reference sources and post on the campus wall in the form of writing "Be Original Don't Plagiarize" see Figure 2 and Figure 3.

\section{PROBLEMS AND CHALLENGES ON THE IMPLEMENTATION OF CAMPUS LIFE ETHICS POLICY AT THE FACULTY OF LAW, SEMARANG STATE UNIVERSITY}

Campus Life Ethics Policy at Semarang State University is an important policy for Semarang State University students because, Ethics is very important for ongoing learning and teaching activities and as one of the supporting factors for the realization of the Vision and Mission of Semarang State University. However, problems and challenges arise in the implementation of the Campus Life Ethics policy. There are two obstacles in implementing Campus Life Ethics Policy, namely internal and external constraints. 


\section{INTERNAL PROBLEMS AND CHALLENGES}

Internal problems and challenges are obstacles that come from the policy makers, or in this case the policy makers Rector's Regulation Number 44 Year 2018 Semarang State University. Judging from Edwards III's view, Edward III argues that policy implementation is influenced by four variables, namely: (1) communication, (2) resources, (3) disposition, and (4) bureaucratic structure. The four variables are also interconnected with each other (Edward III, 1980: 1).

1) Communication

Successful implementation of policies requires that the implementor knows what needs to be done. The Faculty of Law in communicating policies that is through delivery by the Dean and Vice Dean in events or activities on campus, one of which is in PPAK, Banner regarding dress ethics and communication ethics via the telephone to lecturers, and written communication such as displays moral values on the Faculty of Law campus.

2) Resource

Human Resources is positioned as the implementor of the policies. Resources in implementing the policies in this study are, the Chancellor, the Dean, the Vice Dean, the University Student Ethics Board and the Faculty Ethics Council, as well as lecturers and education personnel as well as security guards who act as supervisors.

3) Disposition

Disposition is the character and characteristics of the implementor. if the implementor has a good disposition, then he will run the policy as well as what is desired by policy makers. The characters possessed by the implementor in this research vary or vary, but the diversity of character is actually a good combination in making a policy or implementing a policy.

4) Bureaucratic Structure

The organizational structure in charge of implementing the policy has a significant influence on the policy implementation. One of the important structural aspects of every organization is the existence of standard operating procedures (SOPs). SOP is a guideline for every implementor in acting. Organizational structures that are too long will tend to weaken supervision and lead to red-tape, which is a complex and complex bureaucratic procedure. This in turn results in inflexible organizational activities (Edward III, 1980; 1). 
Ali Masyhar said that the policy making at the University had been adjusted by the existing SOP, the mechanism to try students who had committed violations was already contained in the attachment to Law Number 44 Year 2018.

From Edward's theory, researchers then associate with data from interviews with policy makers. These obstacles were pointed out by Ali Masyhar as the Ethics Board as well as the UNNES Chancellery's Legal Staff, where Ali Masyhar's statement was also approved by the Rector of UNNES as the policy maker.

\section{Communication Obstacle}

Based on information from Ali Masyhar as the Ethics Board and the Rector of Legal Expert Staff, one of the obstacles to the implementation of Campus Life Ethics policy making is the verbal delivery constraints what they want to regulate, the constraints that they want to say (verbal obstacles) that they want to regulate convey in an article.

\section{Human Resource Constraints}

The second obstacle is a constraint in Human Resources. Ali Masyhar explained that for Human Resources there were no obstacles because they were complete, starting from the chairman, deputy, secretary, and member, which meant here was the Ethics Board of Semarang State University. So, there were no obstacles in Human Resources.

\section{Disposition Constraints}

One of the obstacles in implementing policies is the disposition constraint, which is the difference in terms of the character of the policy maker. In the interview Ali Masyhar as the Ethics Board and Expert Staff of the Chancellor of the Law field explained that differences of opinion and character are reasonable, instead they can become a color in policy making, so that it does not become an obstacle, instead it makes color in policy making. 


\section{Bureaucratic Constraints}

Bureaucratic constraints are closely related to SOPs in making any legal product or in this case is policy. Ali Masyhar as the Ethics Board and the Rector of Legal Expert Staff in the interview explained that all policies have been adjusted to the existing SOP.

\section{EXTERNAL PROBLEMS AND CHALLENGES}

External problems and challenges are obstacles faced by policy makers in implementing policies. External constraints are closely related to the still occurring violations committed by students. There are several factors of student abuse. Researchers divide it into 2 factors, namely internal and external factors.

1) Internal factors

Internal factors violations committed by students are factors that arise from within the student. Baidhowi explained that indeed the violation was due to the Human Resources (HR) of the students themselves, the enthusiasm of knowledge, then the human resources of the education staff. influence the occurrence of violations. Khirul Mustaqim (FH UNNES Student, 2014) added that the internal factor in the occurrence of habitual violations committed by the students themselves, for parker violations could be due to rush factors. Anisyah (Chair of DPM KM UNNES 2019 Indonesian Language and Literature Department, 2015) stated that the external factor of violations was the factor of apathetic student culture.

2) External Factors

External factors occurring violations against students are factors outside themselves students. The meaning is external factors that cause students to violate the Ethics of Campus Life. M.Reza Wahyu Artura Putra as a 2017 Faculty of Law Student of UNNES stated that the external factor of violations was the lack of deep socialization. While Setyo Sri Prihatin as a 2016 UNNES FH Student also added that the external factor for violations was the absence of supervisors and strict sanctions. According to Setyo sanctions for violations are less severe. In addition, other factors, namely interference from outside parties or in this case are parties who are not students or community of Semarang State University, are obstacles in the implementation of this Campus Life Ethics policy, in accordance 
with the statement from Baidhowi that other triggers for violations are related to factors facilities provided by the campus.

\section{CONCLUSION}

This study concluded and highlighted that the Normative Urgency of Campus Life Ethics Policy at the Faculty of Law is that the Campus Life Ethics Policy at the Faculty is quite a guideline for students living on the Faculty of Law campus. It is just that in its application there is still a need for in-depth socialization and strict sanctions in its implementation. The Sociological Urgency of Campus Life Ethics Policy at the Faculty of Law, namely the participation of the UNNES community, or in this case, all students, lecturers, education personnel and all leaders or officials of UNNES are still lacking primarily as students, due to their ignorance and lack of understanding of this regulation. Students really need this as forming good student character so that in life on and off campus is also good. The Empirical Urgency of Campus Life Ethics Policy at the Faculty of Law is the importance of in-depth socialization related to Campus Life Ethics. Data in the field shows that there are still some Faculty of Law students who commit violations of student ethics such as smoking in the campus area, cheating, wearing $\mathrm{t}$-shirts and sandals during lectures, parking is not in place. Even though the rules regarding the ethics of campus life have existed but were not given enough attention and heeded by UNNES and Faculty of Law UNNES students because of their ignorance and student misunderstanding regarding the Rector's Regulation.

\section{REFERENCES}

Alam, L. (2016). Internalisasi Nilai-Nilai Pendidikan Islam dalam Perguruan Tinggi Umum Melalui Lembaga Dakwah Kampus. Istawa: Jurnal Pendidikan Islam, 1(2), 101-119. doi:http://dx.doi.org/10.24269/ijpi.vli2.171

Arifin, R., Alkadri, R., Sari, D. P., Resthiningsih, L., \& Holish, A. M. (2019). Improving Law Student Ability on Legal Writing through Critical and Logical Thinking by IRAC Method. Indonesian Journal of Advocacy and Legal Services, 1(1), 107-128.

Asshiddiqie, J., \& Safa'at, M. A. (2006). Theory Hans Kelsen Tentang Hukum. Jakarta: Sekretariat Jendreral \& Kepaniteraan Makamah Konstitusi RI.

Atamimi, A. H. S. (1990). "Peranan Keputusan Presiden Republik Indonesia dalam Penyelenggaraan Pemerintahan Negara: Suatu Studi Analisis Mengenai 
Keputusan Presiden yang Berfungsi Pengaturan dalam Kurun Waktu Pelita I-Pelita IV", Dissertation, Universitas Indonesia, Jakarta.

Dachi, R. A. (2017). Proses dan Analisis Kebijakan Kesehatan (Suatu Pendekatan Konseptual). Yogyakarta: Deepublish.

Dunn, W. N. (2003). Pengantar Analisis Kebijakan Publik. Yogyakarta: Gadjah Mada University Press.

Edward III George C. (1980). Implementing Public Policy. Washington: Congressional Quarterly Press.

Fajar, M., \& Yulianto, A. (2010). Dualisme Penelitian Hukum Normatif \& Empiris. Yogyakarta: Pustaka Belajar.

Farida, M. (1998). Ilmu Perundang-Undangan, Yogyakarta: Kanisius.

Gray, T. (2009). Character Education in Schools. ESSAI, (7), 56-61. Retrieved from http://dc.cod.edu/essai/vol7/issl/21

Haris, A. (2007). Pengantar Etika Islam. Sidoarjo: Al-Afkar.

Hidayat, N. (2017). Rujukan Dan Aplikasi Sistem Hukum Indonesia Berdasarkan Pasal

1 Ayat (3) UUD 1945 Pasca Amandemen Ke Tiga. UIR Law Review, 1(2), 191-200.

Istighfarani, D. (2015). "Peningkatan Hasil Belajar IPS Melalui Model Mind Mapping

Menggunakan Media Jarum Perjuangan Di Kelas V SD Negeri Sokawera", Thesis,

Universitas Muhamadiyah Purwokerto.

Iskandar, P. D., \& Tanya, B. L. (2011). Hukum Etika \& Kekuasaan. Yogyakarta: Genta Publishing.

Jensen, C., Johansson, S., \& Löfström, M. (2018). Policy implementation in the era of accelerating projectification: Synthesizing Matland's conflict-ambiguity model and research on temporary organizations. Public Policy and Administration,33(4), 447-465.

Kurniawan, S. (2014). Pendidikan Karakter: Konsepsi dan Implementasinya secara Terpadu di Lingkungan Keluarga, Sekolah, Perguruan Tinggi \& Masyarakat. Yogyakarta: ArRuzz Media, 2014).

Laudon, K. C., \& Laudon, J. P. (2007). Sistem Informasi Manajemen 1 (Mengelola Perusahaan Digital.Jakarta: Salemba Empat.

Mendes, V. L. P. S., \& Aguiar, F. C. (2017). Implementation of public health policy and its challenges in the digital age. Revista de Administração Pública, 51(6), 1104-1121.

Niravita, A., Sumardiana, B., Wedhatami, B., Salam, S., Kamal, U., Laskarwati, B., \& Syariefudin, I. (2020). How Law Student Prepare Their Life to Survive?. Indonesian Journal of Advocacy and Legal Services, 2(1), 19-38. https://doi.org/10.15294/ijals.v2il.36764

Nuraisyah, N., \& Rozi, S. (2016). Penerapan Nilai-Nilai Akhlak Dalam Peraturan Dan Hukum Formal (Studi Terhadap Kode Etik Mahasiswa STAIN Bukittinggi Tahun 2014). Al Hurriyah: Jurnal Hukum Islam, 1(1), 57-72.

Nurhardianto, F. (2015). Sistem Hukum dan Posisi Hukum Indonesia. Jurnal Tapis: Jurnal Teropong Aspirasi Politik Islam, 11(1), 33-44. 
Patton, M. Q. (2006). Metode Penelitian Kualitatif. Yogyakarta: Pustaka Pelajar.

Prayitno, P., \& Manullang, B. (2011). Pendidikan Karakter dalam Pembangunan Bangsa. Jakarta: Gramedia Widiasara Indonesia.

Republic of Indonesia. (2011). Law Number 12 of 2011 on the Formulation of Laws and Regulations [Undang-undang Nomor 12 Tahun 2011 tentang pembetukan Peraturan Perundang-undangan]. Retrieved from http://bphn.go.id/data/documents/lluu012.pdf

Republic of Indonesia. (2012). Law Number 12 of 2012 concerning Higher Education [Undang-undang Nomor 12 Tahun 2012 Tentang Pendidikan Tinggi]. Retrieved from https://ldikti8.ristekdikti.go.id/2019/02/05/undang-undang-republikindonesia-nomor-12-tahun-2012-tentang-pendidikan-tinggi/

Republic of Indonesia. (2016). Regulation of the Minister of Research, Technology and Higher Education Number 49 of 2016 concerning the Statute of the State University of Semarang [Peraturan Menteri Riset Teknologi dan Pendidikan Tinggi Nomor 49 Tahun 2016 Tentang Statuta Universitas Negeri Semarang]. Retrieved from https:/unnes.ac.id/wp-content/uploads/Permenristekdikti-no49-tahun-2016-ttg-STATUTA.pdf

Rodiyah, R. (2017). The Policy of Conservation for Justice Values on Law School Curriculum on College Incorporated of UNNES (The Justice Value Based Policy of University's Tridharma). International Journal of Business, Economics and Law, 12 (4), 93-98.

Rodiyah, R., Laskarwati, B., Masyhar, A., \& Waspiah, W. (2019). How Should Student Behave? A Legal Ethics and Policy towards Nationalism and AntiRadicalism Characters. JILS (Journal of Indonesian Legal Studies), 4(2), 259-276. https://doi.org/10.15294/jils.v4i2.34343

Saridjo, M. (2011). Pendidikan Islam dari Masa ke Masa: Tinjauan Kebijakan Publik terhadap Pendidikan Islam di Indonesia. Jakarta: Yayasan Ngali Aksara.

UNNES. (2018). Semarang State University Chancellor Regulation Number 44 of 2018 concerning Ethics and Code of Conduct of Semarang State University Students [Peraturan Rektor Universitas Negeri Semarang Nomor 44 Tahun 2018 tentang Etika dan Tata Tertib Mahasiswa Universitas Negeri Semarang]. Retrieved from http://hk.unnes.ac.id/simprokum/files/2018/11/953c7leld8a3f9f2612bf64a02324ea 8.pdf

Zubaedi, Z. (2011). Desain Pendidikan Karakter: Konsepsi dan Aplikasinya dalam Lembaga Pendidikan. Jakarta: Kencana. 